\title{
Geology of the area between Bardibas and Sindhuli Madi, Sub-Himalaya, central Nepal
}

\author{
*Amit Shrestha ${ }^{1}$, Govind Joshi ${ }^{1}$, Lalu Prasad Paudel ${ }^{1}$, Soma Nath Sapkota ${ }^{2}$, and Rafael Almeida ${ }^{3}$ \\ ${ }^{1}$ Central Department of Geology, Tribhuvan University, Kirtipur, Kathmandu, Nepal \\ ${ }^{2}$ Department of Mines and Geology, Lainchaur, Kathmandu, Nepal \\ ${ }^{3}$ Earth Observatory Singapore, Nanyang Tenchnological University, Singapore \\ *Corresponding author: shrestha.amit99@gmail.com
}

\begin{abstract}
The Siwalik Group (Sub-Himalaya) is the east-west extending youngest mountain belt formed by the sediments derived from the rising Himalaya on the north. The Siwalik Group is separated from the Lesser Himalaya to the north by the Main Boundary Thrust (MBT), and the Indo-Gangetic Plain to the south by the Main Frontal Thrust (MFT). The study was carried out mainly along the Ratu Nadi, Kamala Nadi river sections and was lithostratigraphically divided into the Lower Siwalik, Middle Siwalik, and Upper Siwalik, from the bottom to the top section, respectively. The Lower Siwalik is composed of fine-grained greenish grey calcareous sandstone (subarkose and lithic arenite), variegated mudstone, and calcareous siltstone. The Lower Siwalik is exposed due to the Marine Khola Thrust in the Gadyauli Khola, and sandstone there is more indurated and non-calcareous. The Middle Siwalik is mainly comprised of the medium- to coarse-grained salt-and-pepper sandstone (arkose and subarkose) with large cross lamination, calcareous sand lenses, convolute bedding, dark grey siltstone and mudstone. Plant fossils are also present in the finely laminated clay bed of the Middle Siwalik along the Ratu Nadi section. The Upper Siwalik comprises of mud- to sand-supported pebble to cobble conglomerates.
\end{abstract}

Keywords: Lithostratigraphy, Bardibas Thrust, Patu Thrust, Kamala Thrust, Siwalik Group

Paper Received: 7 Jan 2019

Paper Accepted: 8 Apr 2019

\section{INTRODUCTION}

Tectonically, the Sub-Himalayas or the Siwaliks are bounded by Main Boundary Thrust (MBT) in the north and Main Frontal Thrust (MFT) in the south. Many investigators have studied the Siwaliks and have made great deal of contributions to establish the geology of the Siwalik since the end of the 19th century. Itihara et al. (1972), Sah et al. (2000), Corvinus and Nanda (1994) have worked in this area and have mapped the stratigraphic units. Through the preliminary study, the map prepared in the earlier studies was found somewhat not accurate related to the geological contact of the formations. Thus, the aim of present study is to study the stratigraphic units.

The study area is situated, at about $200 \mathrm{~km}$ southeast from Kathmandu, in the Mahhotari and Sindhuli Districts, and lies between the latitudes $27^{\circ} 00^{\prime} 00^{\prime \prime} \mathrm{N}$ to $27^{\circ} 15^{\prime} 00^{\prime \prime} \mathrm{N}$ and longitudes $85^{\circ} 54^{\prime} 00^{\prime \prime} \mathrm{E}$ to $86^{\circ} 03^{\prime} 00^{\prime \prime} \mathrm{E}$ (Fig. 1). The study area falls in between the Bardibas area (south) and Sindhulimadi (north). The study area is easily accessible through roadways. Two major highways, Prithivi-Mahendra Highway and B. P. Highway connect the area.

\section{METHODOLOGY}

Three topo sheets (2685-04B, 2785-16D, 2785-16B provided by the Department of Survey, Government of Nepal) of scale 1:25,000 were used as base maps to locate the actual position of the outcrop and to plot the attitude of the outcrop during mapping.

The $5 \mathrm{~m}$ digital elevation model in conjunction with the satellite image from Google Earth along with LiDAR image were also used for the location of well exposed outcrops and tentative bedding orientation. For the better understanding of the lithology and locating the geological contact the route maps of 1:2,000-scale were prepared. Columnar sections were also made along the formation boundary and well exposed outcrop. Samples of sandstone and other rocks were collected to identify their types in laboratory. Three-fold classification of the Siwalik was adopted to establish the lithostratigraphy of the study area. The lithological units using the three-fold classification system are: Lower Siwalik, Middle Siwalik and Upper Siwalik, respectively.

\section{LITHOSTRATIGRAPHY}

The Siwalik Group of the study area is lithostratigraphically divided into the Lower Siwalik, the Middle Siwalik and the Upper Siwalik from the bottom to the top, respectively. The distribution of the Siwalik Group can be recognized into four thrust belts between; the Bardibas Thrust and the Patu Thrust, the Patu Thrust and the Kamala Thrust, the Kamala Thrust and the Marine Khola Thrust and the Marine Khola Thrust and the MBT, respectively from the south to the north of the study area (Figs. 2 and 3). The total thickness of 


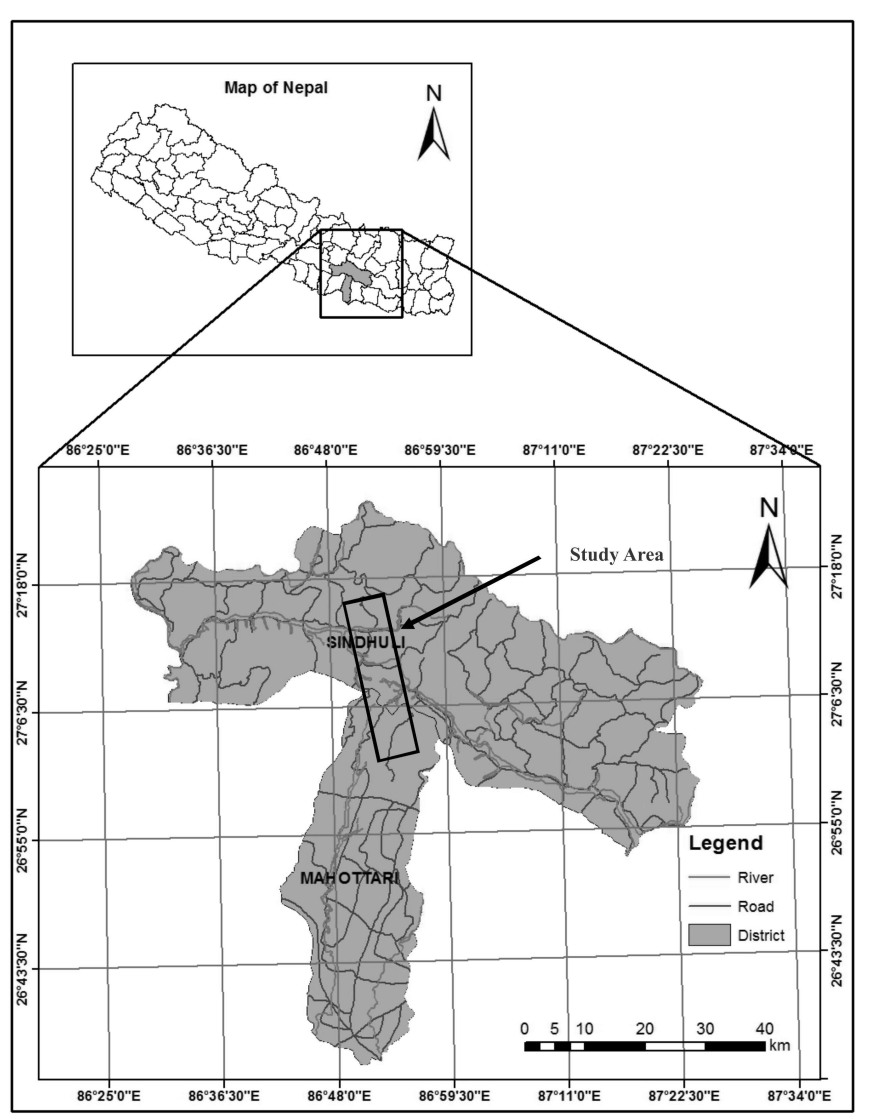

Fig. 1: Location map of study area

the Siwalik Group in the study area along the Ratu River and B.P. Highway is $3800 \mathrm{~m}$, of which the thicknesses of the Lower, Middle and the Upper Siwaliks are respectively 1550 m, 1500 $\mathrm{m}$ and $750 \mathrm{~m}$.

\section{Lower Siwalik}

The Lower Siwalik is mainly exposed in two belts in the study area i.e. between the Kamala Thrust and Marine Khola Thrust, and between the Marine Khola Thrust and the MBT (Fig. 2). The strata of the Lower Siwalik on both of the thrust belts extend parallel (NW-SE) to the thrust. The main lithology of the Lower Siwalik is fine-grained, greenish grey indurated sandstone along with mudstone and siltstone. The sandstone on the thrust belt between the Marine Khola Thrust and the MBT is highly indurated and less calcareous.

\section{Lower Siwalik between Kamala Thrust and Marine Khola Thrust belt}

The outcrop is well exposed along the Kamala Nadi at the Bhiman Village, around Kulogau, confluence of the Sindhure Khola and the Kamala River (Fig. 2). The outcrop near the Bhiman Village is mainly dominated by the red to dark gray calcareous mudstone. Along with mudstone, greenish grey sandstone and light to dark grey calcareous siltstone with nodular weathering pattern is observed. The succession is thrusted over the Upper Siwalik by the Kamala Thrust and is overlain by the Middle Siwalik with a transitional contact. The succession is also characterized by many small-scale syncline and anticline that can be observed near the confluence of the Kamala Nadi and the Sindhure Khola. The general attitude of the formation trends in NW-SE direction. The width of the formation is about 250-300 m.

\section{Lower Siwalik between Marine Khola Thrust and MBT belt}

The Lower Siwalik succession is well exposed in the Jasedmar Village along the Gadyauli Khola (north east of the Sindhulimadi Bazar) (Fig. 2). The succession is well exposed all along the Gadyauli Khola upto the confluence of the Gairamtar Khola near the Niure Village, and is characterized by the finegrained, indurated greenish grey slightly calcareous sandstone occurring dominantly along with pale yellow to red mudstone (Fig. 4) and siltstone. The presence of local anticline and polished surface of mudstone from the anticline core indicates some sort of shearing. The overall orientation of strike is NW-SE direction. The width of the formation is $1800 \mathrm{~m}$. The formation shows the fining upward cycles.

Some of the sandstones from the Lower Siwalik belong to subarkose and lithic arenite (Table 1). Subarkose are finegrained and poorly to moderately sorted (Fig. 5).

\section{Middle Siwalik}

The Middle Siwalik is well exposed repeatedly three times in the study area in three thrust belts: between the Patu Thrust and the Kamala Thrust, between the Kamala Thrust and the Marine Khola Thrust, and between the Marine Khola Thrust and the MBT. This succession is well exposed on both banks the Ratu Nadi upto the Kalapani Village, Kamala Nadi section near Maithan temple and the Gairamtar Khola. The succession continues as the core of an anticline formed due to the Patu Thrust on the Ratu Nadi, Patu Village. The exposed rocks of the succession mainly comprised of sandstone, siltstone, mudstone and finely laminated clay beds with fossil content.

\section{Middle Siwalik between Patu Thrust and Kamala Thrust belt}

The succession is exposed near the Patu Village along the Ratu Nadi and along the Bimire Khola sections. The unit is not uniformly distributed along the thrust. The beds are extended towards the northwest and pinched out towards the east. The surface width of the formation varies from middle portion of the study area to the northwest part of the area. The succession is $1050 \mathrm{~m}$ wide in the middle of the study area and towards west it is $3900 \mathrm{~m}$ wide. The succession is characterized by the dominance of light grey, medium to coarse grained, very thick bedded multi-storied $(20-30 \mathrm{~m})$ salt and pepper texture 


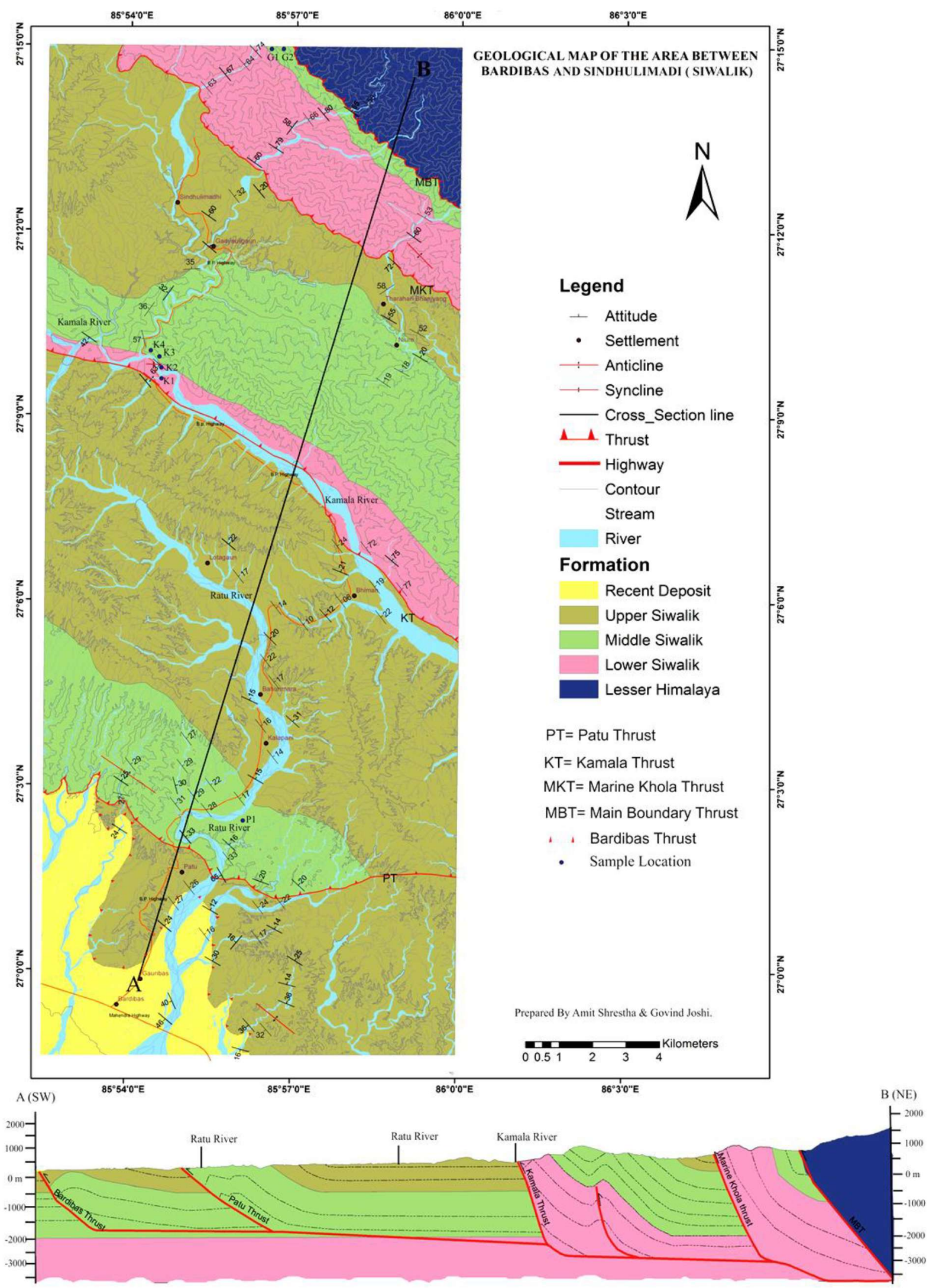

Geological cross-section along the line A-B

Fig. 2: Geological map of the study area 


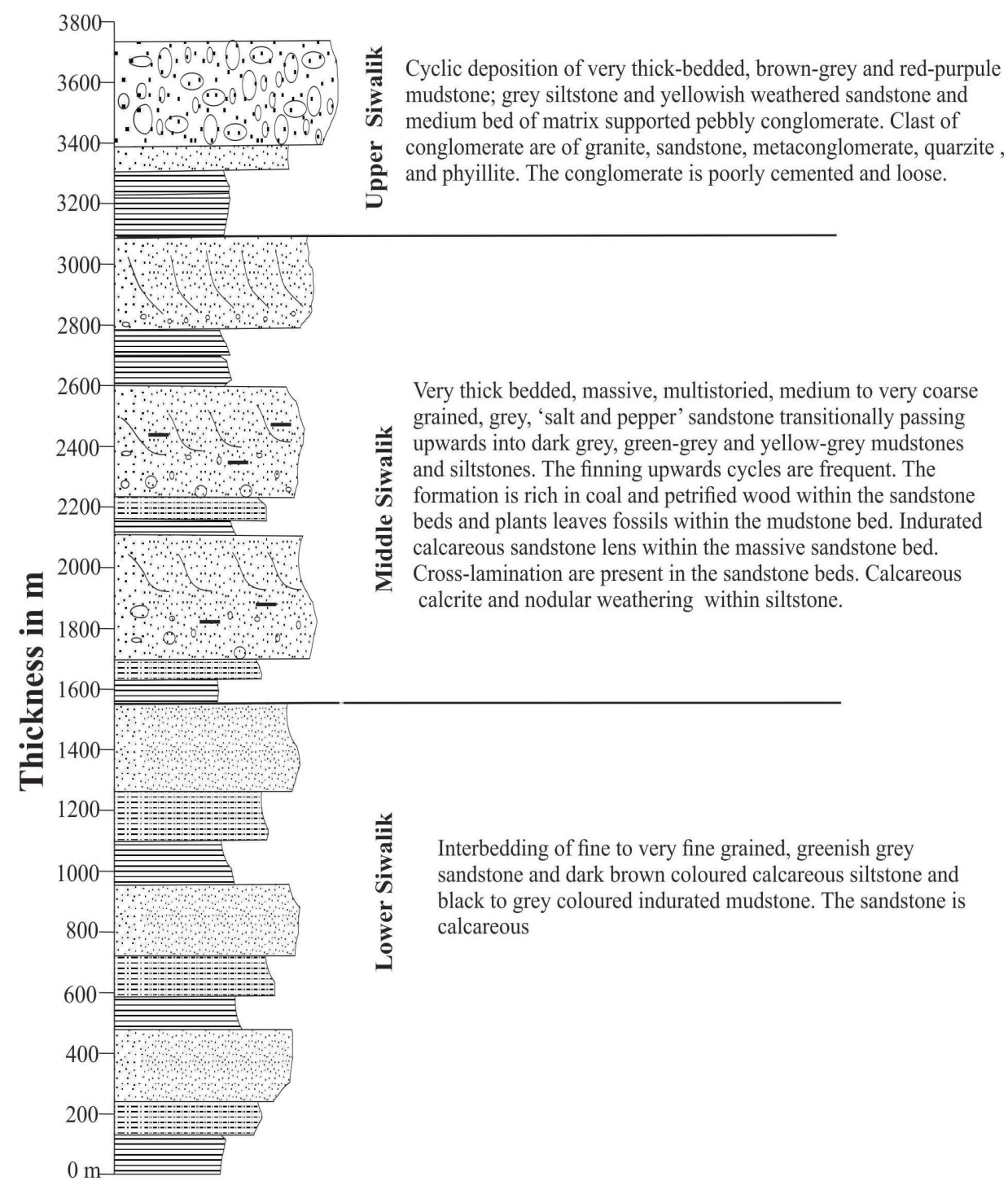

Fig. 3: Generalized columnar section of the study area

sandstone. The massive bed of sandstone is intercalated by grey to dark grey siltstone and mudstone. The mudstone and siltstone are highly deformed and crushed. The crumbled and polished surface of the deformed mudstone and siltstone indicate the presence of nearby fault or thrust or active stress. The medium to coarse grained salt and pepper sandstone are dominant with large cross lamination (Fig. 6), convolute beddings, cut and fill structures. The sequence also consists of calcareous sandstone lenses within the beds of salt and pepper sandstone. The calcareous sandstone lenses are competent, indurated and is very fine grained as compared to the previous described salt and pepper sandstone. The general orientation of the beds is NW-SE and the bed dips towards the north. The formation rides over the younger Upper Siwalik due to Patu Thrust (Sapkota et al., 2013) and is overlain by the mud-dominance conglomerate of the Upper Siwalik in the north.

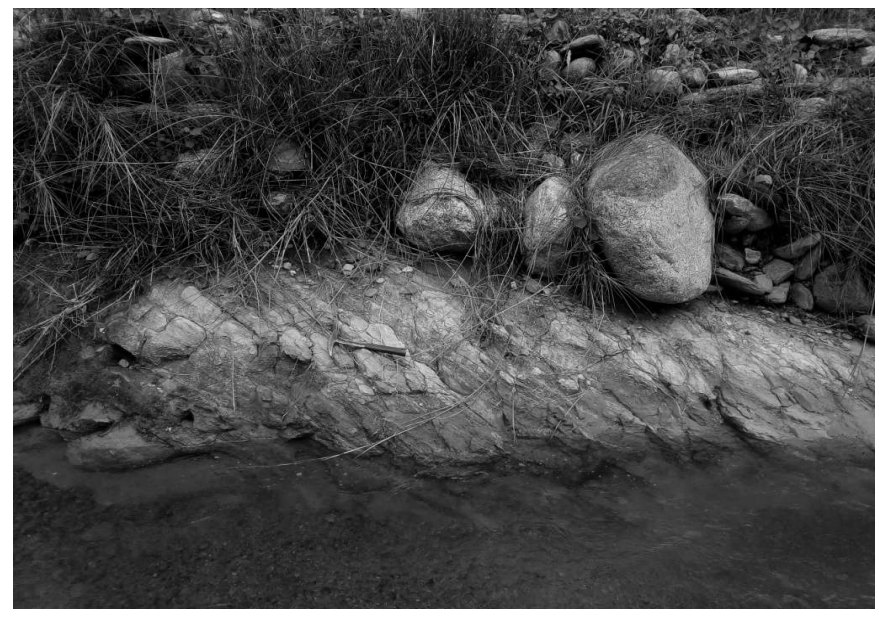

Fig. 4: Pale yellow to red mudstone outcrop, Lower Siwalik 

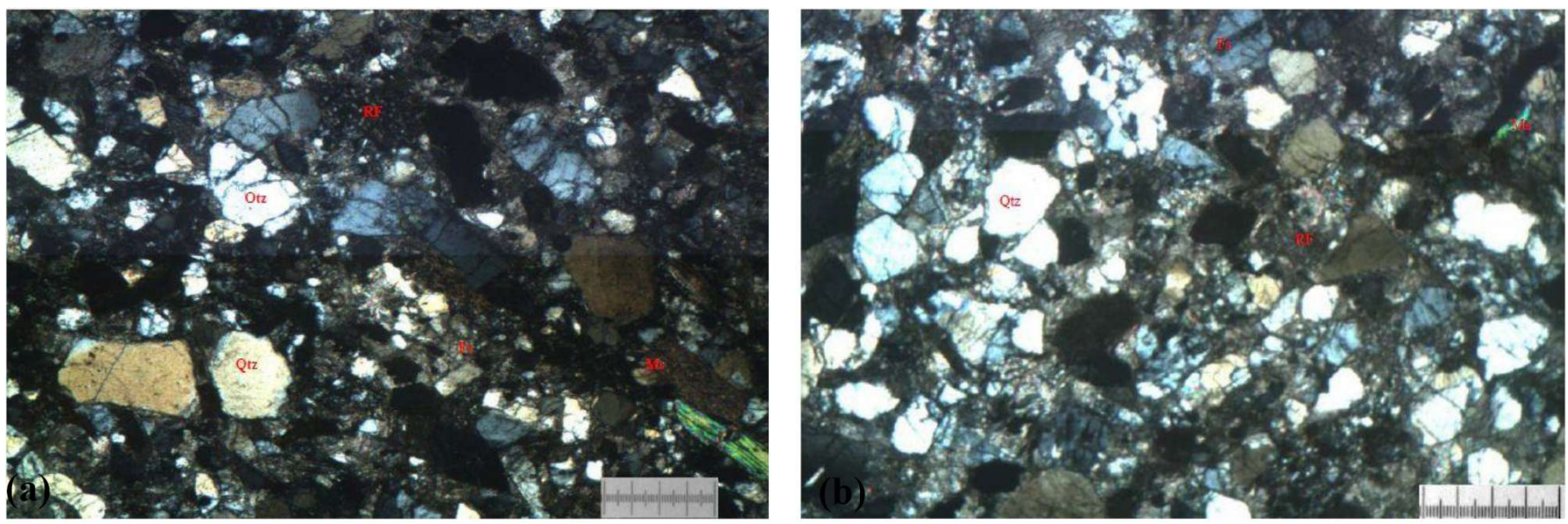

Fig. 5: Photomicrographs of sandstones (4x10, UCN, 1division =0.02 mm): (a) Sample K1 and (b) Sample K3

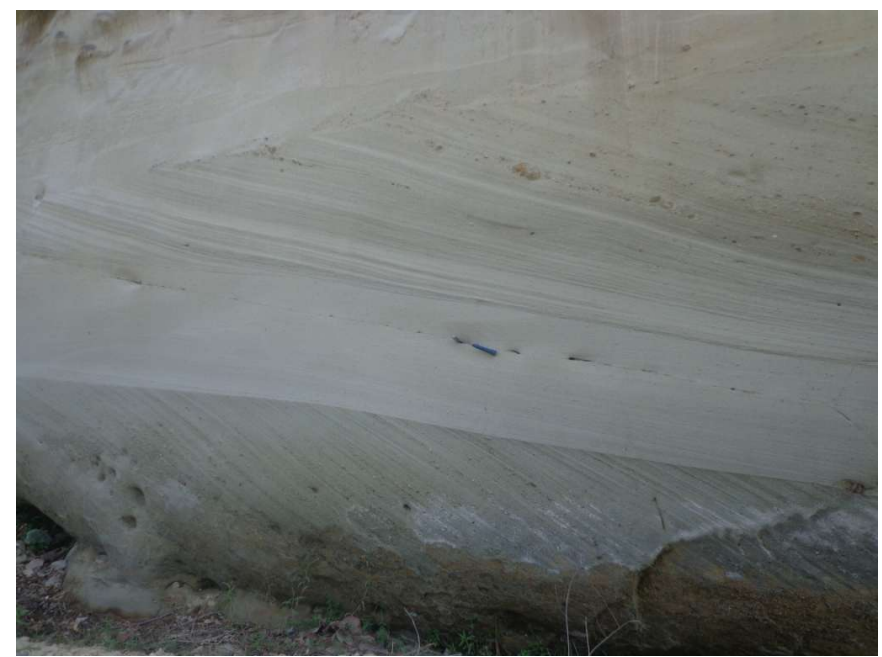

Fig. 6: Cross lamination on Sandstone bed, Middle Siwalik

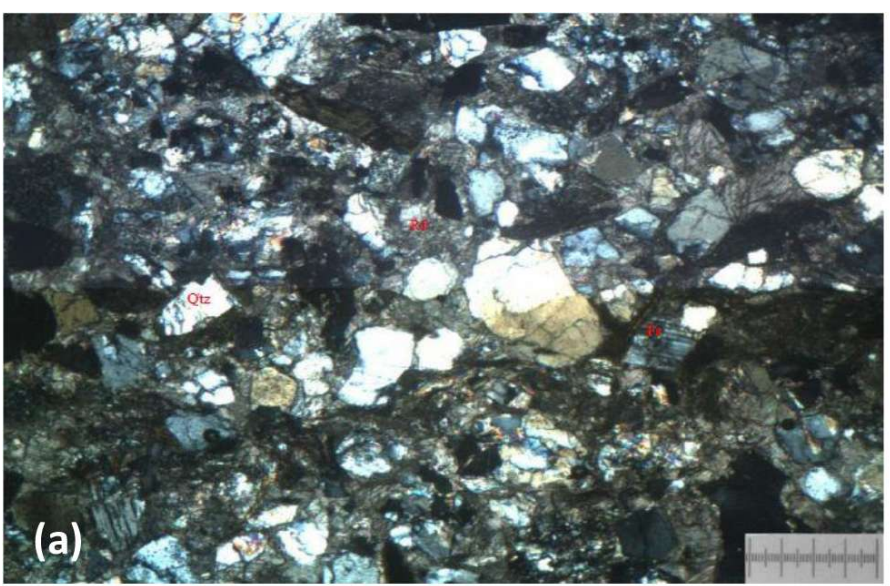

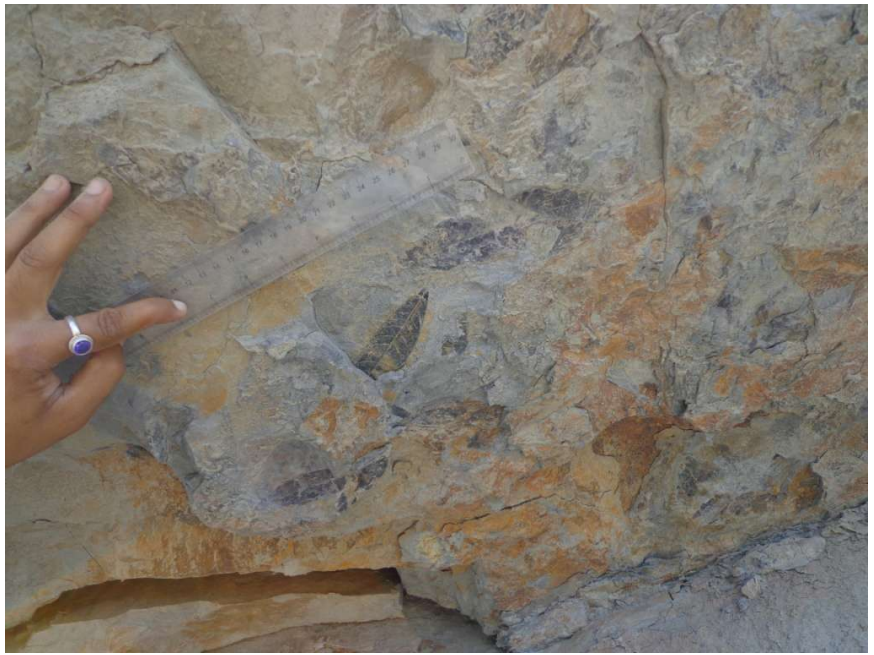

Fig. 7: Dicotyledons plant fossil preserved on sandstone bed of Middle Siwalik

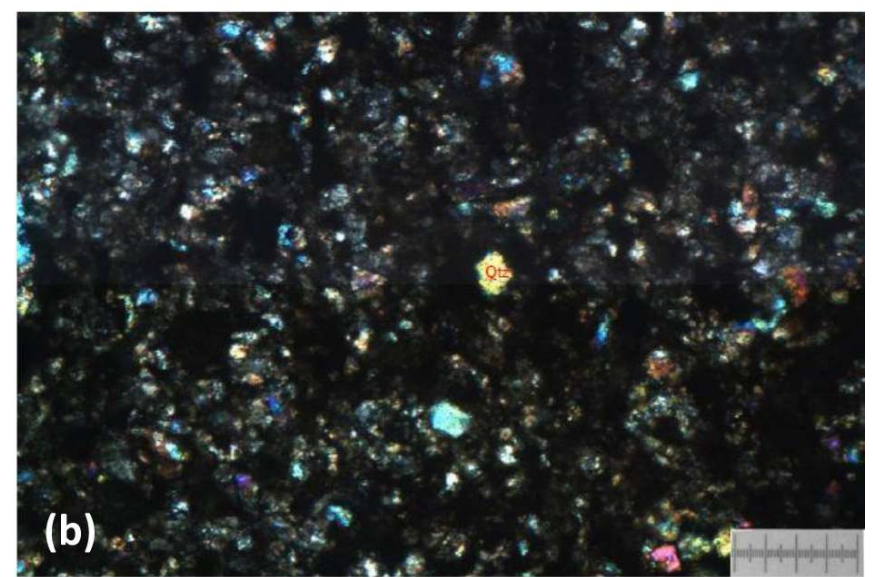

Fig. 8: Photomicrographs of sandstones (4x10, UCN, 1division = 0.02 mm): (a) Sample P1, and Sample G2 


\section{Middle Siwalik between Kamala Thrust and Marine Khola}

\section{Thrust belt}

The succession is well exposed along the Kamala Nadi and the Gwan Khola sections. The litho unit is well exposed continuously through the thrust belt but the width of the succession varies. The unit is narrower towards west and broad towards east. The width to the west is about $2300 \mathrm{~m}$ and to the east is about $5000 \mathrm{~m}$. The succession mainly consists of finegrained sandstone to coarse grained salt and pepper sandstone. Mudstone and sandstone both are thick bedded.

Near Bukka Village on B. P. Highway above confluence of the Bukka Khola and the Labdhai Khola, plant fossil of different species of dicotyledonous plants (Fig. 7) was observed. The upper part of the Middle Siwalik here is characterized by presence of coarse- grained pebbly sandstone with $25 \mathrm{~cm}$ thickness of the pebble bed.

\section{Middle Siwalik between Marine Khola Thrust and MBT belt}

The succession is well exposed along the Gairamtar Khola, the Chiyabari area along the Gwan Khola section and road section of the Chiyabari Village. The outcrop of the Middle Siwalik is continuous and has almost uniform width of 200-250 $\mathrm{m}$. The succession mainly comprises of the salt-and-pepper sandstone, which is much indurated as compared to the sandstone of the Middle Siwalik of other sections within the study area, and also the biotite content is very less. The thickness of the sandstone bed is 5-7 m. The sandstone is followed by thinly laminated mudstone. The general trend of the bed in the area is NW-SE and the bed dips towards north. The succession is bounded by the Lower Siwalik in the south and by MBT in the north.

The sandstones from the Middle Siwalik are salt-andpepper textured, poorly sorted, coarse-grained and arkosic (Fig. 8a) to fine-grained subarkosic (Fig. 8b) (Table 1).

\section{Upper Siwalik}

This succession is well exposed three times in the study area along three thrust belts: between the Bardibas Thrust and the Patu Thrust, between the Patu Thrust and the Kamala Thrust, and between the Kamala Thrust and the Marine Khola Thrust (Fig. 2). The Upper Siwalik succession in the area mainly comprises of mud matrix-supported conglomerate, and sandmatrix and clast-supported conglomerate. The thickness of the formation is $750 \mathrm{~m}$.

\section{Upper Siwalik between Bardibas Thrust and Patu Thrust belt}

The succession is mainly exposed along the Ratu Nadi near the Gauridada Village, north of Bardibas (Fig. 2). The succession mainly consists of pebble to cobble conglomerates, medium- to coarse-grained sandstone with little amount of mica, siltstone and mudstone. At the lower part of the formation, the mudstone and siltstone is dominant. Near the Gauridada Village along the Ratu Nadi, the rock unit consists of massive beds of conglomerates. The thickness of conglomerate bed reaches upto $25 \mathrm{~m}$. The conglomerates are well sorted and consist of rounded to sub-rounded pebbles of quartzite, sandstone, metasandstone, granite, etc. The clast of quartzite dominates the other. The general trend of the strike is NW-SE and the bed dips toward north. The formation is bounded by the Bardibas Thrust in the south and Patu Thrust in the north.

\section{Upper Siwalik between Patu Thrust and Kamala Thrust belt}

The succession is repeated due to Patu Thrust and is exposed at Kalapni area along Ratu Khola to Lotagau (Lota Kharhare River), Bhiman Village (Fig. 2). The succession is uniformly distributed between Patu Thrust and Kamala Thrust Belt. The rock succession mainly comprises of claystone, red

Table 1: Sandstones of the study area after Dott's classification (Pettijohn, 1984)

\begin{tabular}{|c|c|c|c|c|c|c|c|c|c|c|c|}
\hline \multirow[t]{2}{*}{$\begin{array}{l}\text { Sample } \\
\text { No. }\end{array}$} & \multirow[t]{2}{*}{ Formation } & \multicolumn{6}{|c|}{ Composition $\%$} & \multicolumn{3}{|c|}{$\begin{array}{l}\text { Recalculated \% of Quartz, } \\
\text { Feldspar and Rock-Fragments }\end{array}$} & \multirow[t]{2}{*}{$\begin{array}{l}\text { Rock } \\
\text { Name }\end{array}$} \\
\hline & & Quartz & Feldspar & $\begin{array}{l}\text { Rock- } \\
\text { Fragments }\end{array}$ & Muscovite & Biotite & Matrix & Quartz & Feldspar & $\begin{array}{l}\text { Rock- } \\
\text { Fragments }\end{array}$ & \\
\hline $\mathrm{K} 1$ & $\begin{array}{l}\text { Lower } \\
\text { Siwalik }\end{array}$ & 60 & 17 & 6 & 3 & 6 & 8 & 72.29 & 20.48 & 7.23 & $\begin{array}{l}\text { Sub- } \\
\text { arkose }\end{array}$ \\
\hline $\mathrm{K} 2$ & & 65 & 14 & 5 & 2 & 3 & 11 & 77.38 & 16.67 & 5.95 & $\begin{array}{l}\text { Sub- } \\
\text { arkose }\end{array}$ \\
\hline $\mathrm{K} 3$ & & 62 & 10 & 7 & 4 & 5 & 12 & 78.48 & 12.66 & 8.86 & $\begin{array}{l}\text { Sub- } \\
\text { arkose }\end{array}$ \\
\hline K4 & & 55 & 11 & 18 & 2 & 3 & 8 & 65.48 & 13.10 & 21.43 & $\begin{array}{l}\text { Lithic- } \\
\text { arenite }\end{array}$ \\
\hline $\mathrm{P} 1$ & $\begin{array}{l}\text { Middle } \\
\text { Siwalik }\end{array}$ & 55 & 20 & 5 & 6 & 9 & 5 & 68.75 & 25.00 & 6.25 & $\begin{array}{l}\text { Arkosic- } \\
\text { arenite }\end{array}$ \\
\hline G1 & & 64 & 18 & 6 & 2 & 3 & 7 & 72.73 & 20.45 & 6.82 & $\begin{array}{l}\text { Sub- } \\
\text { arkose }\end{array}$ \\
\hline $\mathrm{G} 2$ & & 67 & 20 & 6 & 1 & 2 & 4 & 72.04 & 21.51 & 6.45 & $\begin{array}{c}\text { Sub- } \\
\text { arkose }\end{array}$ \\
\hline
\end{tabular}


mudstone, along with pale yellow sandstone and grey siltstone. The pale yellow color of sandstone is due to the weathering of biotite. The mud-supported conglomerate is mainly matrix supported with clast size ranging from pebble to cobble size. The clast is of sandstone, quartzite, granite, and dolomite. The outcrop has dominance of muddy pebbly conglomerate along with sandstone; siltstone and red mudstone. The succession is also characterized by the sand-supported conglomerate and is well exposed along the Lotagau, Maithan Village, Bhiman and Hattisargau villages. The rock succession is mainly comprised of pebble to cobble conglomerate. The conglomerate is sand matrix dominant and the clast is of sandstone, dolomite, phyllite, metasandstone, metaconglomerate and granite.

\section{Upper Siwalik between Kamala Thrust and Marine Khola Thrust belt}

The formation mainly comprises of the mud-supported pebbly conglomerate along with pale yellow to red mudstone, dark gray siltstone and sandstone. The clasts are of sandstone, metasandstone, quartzite, granite, etc. The succession is also characterized my small scale folds. The overall orientation of the strike is NW-SE and bed dips towards the north.

\section{DISCUSSIONS}

Few researchers have worked in the study area. Itihara et al. (1972) divided the Siwaliks of the area into three-fold classifications (Lower, Middle and Upper) on the basis of aerial photograph. Boundaries defined on the basis of aerial photograph does not match with the present study. Sah et al. (2000) also mapped the Rato Khola section and they divided the Siwaliks of the area in seven different formations: Khairani Formation, Maithan Formation, Patu Formation, Gwang Khola Formation, Bhiman Formation and Post Siwalik Formation and also showed that the area has north dipping beds only without any folds but present study contradicts Sah et al. (2000)'s work. According to the present study, only three-fold classification is possible and the area has two regional scale anticlines: Kamala Frontal Anticline (Pradhan et al. 2005), Bakaiya Anticline (Pradhan et al. 2002) and with many small-scale folds. Therefore, the lithostratigraphy of the study area after the data analysis can be divided into three litho-units namely: Lower Siwalik, Middle Siwalik and Upper Siwalik. There litho units are repeated several times by the thrust sheets.

The Lower Siwalik mainly consists of the fine grained greenish grey sandstone along with thin beds of grey siltstone and medium grained compacted sandstone. The sandstone of this succession is much indurated and less calcareous. The Middle Siwalik is mainly characterized by the massive mediumto coarse-grained salt-and-pepper sandstones with large crosslamination, convolute beddings, cut and fill structures. The sequence also consists of calcareous sandstone lenses within the beds of salt-and-pepper sandstone. The sandstones of Middle Siwalik possess less biotite content as compared to the sandstones of the Middle Siwalik in the western region of the study area, studied by previous researchers (Hisatomi, 1992; Tamrakar et al., 2003; Tamrakar and Syangbo, 2014).

The Upper Siwalik comprise of mudstone, siltstone, sandstone and pebbly conglomerate. Pale yellow mudstone dominates grey siltstone and fine-grained grey sandstone. Mud dominant pebbly conglomerate with subordinate sandstones suggests its deposition by gravelly braided river system. The occurrences of pebbles of quartzite, dolomite, metasandstone suggests it was mainly from the Lesser Himalaya and partly from the Siwaliks. The Upper Siwalik is also characterized by sand dominant conglomerate and the clast is of sandstone, dolomite, phyllite, metasandstone, metaconglomerate, granite. The clast of the conglomerate shows that its provenance was Lesser Himalaya and Higher Himalaya.

The lithostratigraphy of the present study is compared with the lithostratigraphy after Dhital et al. (1995) along the Surai Khola section, Tokuoka et al. (1986) along western part of the Arung Khola area, and after Sah et al. (1994) and Ulak and Nakayama (1998) along the Amlekhganj-Hetauda section (Table 2). The Lower Siwalik, Middle and the Upper Siwalik of the present study area mapped, are comparable respectively to the lithostratigraphic units of Sah et al. (1994) and Ulak and Nakayama (1998) such as the Rapti Formation, Amlekghganu Formation, and the Churia Khola and the Churia Mai Formations.

\section{CONCLUSIONS}

The study area between the Bardibas and Chiyabari lies in the Sub-Himalaya zone. The rock successions of the study area are divided into three litho-units: Lower Siwalik, Middle Siwalik, and Upper Siwalik, respectively. In the study area the formation are divided based on the variation of lithology. The fluvial deposit of the Siwalik as a whole shows the coarsening upward sequence where as fining upward cycle is recorded in individual litho units. The litho-units are deformed and repeated in the study area by major thrust sheets namely the Bardibas Thrust, the Patu Thrust, the Kamala Thrust, the Marine Khola Thrust and the Main Boundary Thrust. Due to thrusting the study area comprises of major regional fold structures as well local folds. The Kamala Frontal Anticline and the Bakiya Anticline are the regional folds. Few sandstones are categorized as subarkose, lithic arenite and arkose. The Upper Siwalik conglomerates contain clasts derived from the Lesser Himalaya, Higher Himalaya and the Sub-Himalaya itself. The Lower Siwalik and the Middle Siwaliks of the present study are comparable to the Rapti Formation and the Amlekhganj Formation, while the Upper Siwalik is comparable to the Churia Khola and the Churia Mai Formations of the AmlekhganjHetauda region.

\section{ACKNOWLEDGEMENTS}

Authors express their sincere gratitude to Earth Observatory Singapore for financial Support and would like to thank Prof. Dr. Megh Raj Dhital and Dr. Judith Hubbard for 
Table 2: Showing lithostratigraphic comparison of the present study with earlier works

\begin{tabular}{|c|c|c|c|c|c|}
\hline $\begin{array}{l}\text { Tokuoka et } \\
\text { al. (1986) }\end{array}$ & $\begin{array}{c}\text { Heatauda (Sah et al. } \\
\qquad 1994 \text { ) }\end{array}$ & $\begin{array}{l}\text { Surai Khola, Dhital et al. } \\
\text { (1995) }\end{array}$ & $\begin{array}{c}\text { Ulak and } \\
\text { Nakayama } \\
(1998)\end{array}$ & $\begin{array}{c}\text { Sha et al. (2000), } \\
\text { Rato Khola }\end{array}$ & $\begin{array}{c}\text { Present Study } \\
\text { Bardibas to } \\
\text { Sindhulimadi area }\end{array}$ \\
\hline & & & & $\begin{array}{c}\text { Post Siwalik } \\
\text { Deposition }\end{array}$ & \\
\hline $\begin{array}{c}\text { Deorali } \\
\text { Formation }\end{array}$ & Churia Mai Formation & DhanKhola Formation & $\begin{array}{l}\text { Churia Mai } \\
\text { Formation }\end{array}$ & Bhiman Formation & \multirow[t]{2}{*}{ Upper Siwalik } \\
\hline $\begin{array}{l}\text { Chitwan } \\
\text { Formation }\end{array}$ & $\begin{array}{l}\text { Churia Khola } \\
\text { Formation }\end{array}$ & Dobata Formation & $\begin{array}{l}\text { Churia Khola } \\
\text { Formation }\end{array}$ & Gauridada Formation & \\
\hline \multirow{2}{*}{$\begin{array}{l}\text { Binai Khola } \\
\text { Formation }\end{array}$} & \multirow{2}{*}{$\begin{array}{l}\text { Amlekhganj } \\
\text { Formation }\end{array}$} & Surai Khola Formation & \multirow{2}{*}{$\begin{array}{l}\text { Amlekhganj } \\
\text { Formation }\end{array}$} & $\begin{array}{l}\text { Gwan Khola } \\
\text { Foramation }\end{array}$ & \multirow[t]{2}{*}{ Middle Siwalik } \\
\hline & & ChorKhola Formation & & Patu Formation & \\
\hline \multirow{2}{*}{$\begin{array}{l}\text { Arung Khola } \\
\text { Formation }\end{array}$} & \multirow{2}{*}{ Rapti Formation } & Jangli Khola Member & & Maithan Formation & \multirow{2}{*}{ Lower Siwalik } \\
\hline & & Bankas Formation & Formation & Khairani Formation & \\
\hline
\end{tabular}

their valuable suggestions. They are also thankful to two anonymous reviewers for their fruitful comments to improve this manuscript.

\section{REFERENCES}

Corvinus, G. and Nanda, A.C., 1994, Stratigraphy and paleontology of the Siwalik Group of Surai Khola and Rato Khola in Nepal. N. Jb. Geol. Paläont. Abh, v. 191 (1), pp. 25-68.

Dhital, M.R., Gajurel, A.P., Pathak, D., Paudel, L.P., and Kizaki, K., 1995, Geology and structure of the Siwaliks and Lesser Himalaya in the Surai Khola-Bardanda area, Mid- Western Nepal. Bulletin of Department of Geology, Tribhuvan University, v. 4, special issue, pp. $1-70$.

Hisatomi, K., 1992, The sandstone petrology and the provenance of the Churia Group in $\mathrm{the} \quad \mathrm{Arung}$ Khola-Binai Khola area, west central Nepal. Bulletin of Department of Geology Tribhuvan University, v. 2, pp. 89-105.

Itihara, M., Shibasaki, T., and Miyamoto, N., 1972, Photogeological survey of the Siwalik Ranges and the Terai Plain, Southeastern Nepal. Journal of Geosciences, Osaka City University, v. 15, Art 4, pp. 77-98.

Pettijohn, F.J., 1984, Sedimentary Rocks. Third edition, CBS Publication., $628 \mathrm{p}$.

Pradhan, U.M.S., Shrestha, R.B., KC, S.B., and Sharma, S.R., 2002, Geological map of petroleum exploration block-7, Malangawa, Central Nepal (Scale: 1:250,000). Petroleum Exploration Promotion Project, Department of Mines and Geology, Kathmandu.

Pradhan, U.M.S., Sharma, S.R., and Tripathi, G.N., 2005, Geological map of petroleum exploration block-9, Rajbiraj,
Eastern Nepal (Scale:1:250,000). Petroleum Exploration Promotion Project, Department of Mines and Geology, Kathmandu.

Sah, R.B., Ulak, P.D., Gajurel, A.P., and Rimal, L.N., 1994, Lithostratigraphy of Siwalik sediments of HetaudaAmlekhgunj area, Sub-Himalaya of Nepal. Himalaya Geology, v. 15, pp. 37-48.

Sah, R.B., Shrestha, P.M., Mulmee, M.R., and Budathoki, R., 2000, Geology and new fossil record of an extinct elephant from the Siwalik succession of Rato Khola a r e a , Sub-Himalaya, Eastern Nepal. Journal of Stratigraphic Association of Nepal, v. 2, pp. 29-41.

Sapkota, S.N., Bollinger, L., Klinger, Y., Tapponnier, P., Gaudemer, Y., and Tiwari, D., 2013, Primary surface rupture of the great Himalayan earthquakes of 1934 and 1255. Nature Geoscience, v. 6, pp. 71-76. https://doi.org/10.1038/ngeo1669

Tamrakar, N.K., Yokkota, S., Shrestha, S.D., 2003, Petrography of the Siwalik Sandstones, Amlekhganj-Suparitar area, Central Nepal Himalaya, Journal of Nepal Geological Society, v. 28, pp. 41-56.

Tamrakar, N.K. and Syangbo, D.K., 2014, Petrography and provenance of the Siwalik Group sandstones from the Main Boundary Thrust region, Samari River area,

Central Nepal, sub-Himalaya. Boletín de Geología, v.36(2), pp. 25-44.

Tokuoka. T., Takayasu, K., Yoshida, M., and Hisatomi, K., 1986, The Churia (Siwalik) Group in the Western part of the Arun Khola area, West Central Nepal. Mem. Fac. Shim. Univ. 22, pp. 131-143.

Ulak, P.D. and Nakayama, K., 1998, Lithostratigraphy andevolution of fluvial style of the Siwalik Group in theHetauda-Bakiya Khola area, central Nepal. Bull. Dept. Geo., Tribhuvan Univ., Kathmandu Nepal, v. 6, pp. 1-14. 